hair is dark and thick, the nose flat, and the chin pointed. A skull which Barnard Davis succeeded in sending to England was found to have a capacity of 1638 cubic centimetres, with horizontal and vertical indices of 77.3 and 78.3 respectively. They have the reputation of being a bloodthirsty and inhospitable people, but they have now succeeded better than any of the neighbouring tribes in drawing closer to the Russians. They frequently change their paganism for the Russian Orthodox Church. The Japanese, with whom they traded in the southern part of Saghalin, have had no great influence over them. Sometimes they live in houses which are built on piles raised some distance above the ground, with a platform, or balcony around, on which they lay their sledges, nets, \&c. From the roof are suspended hundreds of salmon, put there to be smoked and dried. The men pas; $m$ sst of the time away from their families, fishing or hunting. They are eipecially fond of the dolphin, but as they have but bad weapons of the chase, they rarely succeed in catching this fish. When they do, however, the occa:ion is kept as a festival. As with most of the aborigines of North-Eastern Asia, they reverence the bear as a divinity, but it is nevertheless almost invariably slaughtered. Their proceedings at the festival of the bear resemble those of the Ainos of Yezo, drunkenness being the order of the day. The religion of the Gilyaks is Shamanism with all its superstitions. They will allow no one to take a spark of fire, even in a tobacco-pipe, from their huts, believing that ill-luck and misfortune will follow. The bodies of the dead are burned, and a small house erected above the ashes, while a favourite hound is slaughtered on the grave. The Gilyaks in Saghalin differ in some respects from those on the mainland. Their mode of living differs little from that of the Ainos. Marriage is not permitted among members of the same family; wives are purchased, but also captured. The Japanese traveller, Mamia Rinso, who thoroughly examined the whole of Saghalin and the neighbouring coast about the beginning of this century, says that pulyandry existed amongst them. They are the most superstitious of all the Tungusic tribes in the Amour region, as well as the most cruel in their customs.

THE United States war-steamer Palos has been engaged for some time past, by order of the American Government, in carrying out a series of observations in China and Japan with the object of ascertaining the correct latitude and longitude of certain important points. The position of Wladivostock was determined by Russian engineers some years ago, and the object of the present expedition is to settle those of the chief centres between that place and Madras, e.g. Nagasaki, Amoy, Shanghai, Hongkong, and Singapore. The positions of the first three have been determined, and it is said do not show any. great discrepancy with those hitherto accepted.

THE December number of the Geographical Society's Pro ceedings opens with Mr. F. A. A. Simons' paper on the Sierra Nevada of Santa Marta and its watershed, accompanied by a gosd map of the region from his own survey. Mr. Delmar Morgan contributes a paper on steppe-routes from Karshi to the Amu-daria, being an annotated rendering of one by M. Maief in the Russian Geographical Society's Isvestia. In the Geographical Notes the new Russo-Chinese frontier is described, and there is an interesting note on the old map of Djungaria by the Swede Renat, recently discovered in the library of Linköping. M. Wiener's discovery of the Samiriá tributary of the Upper Marañon is also referred to, and it is stated that he has constructed a map of this almost unknown region. Perhaps the most interesting item in the whole number is the short letter from Capt. Gray, of Peterhead, on the recent advance of the Polar ice in the Greenland and Spitzbergen Sea, with its accompanying ice-chart. A long report on the Venice Congress and Exhibition is furnished by Capt. A. W. Baird, R.E., and is the only one, so far as we know, which has yet been published.

THE last Bulletin of the Commercial Geographical Society of Bordeaux contains some notes on M. Ch. Wiener's extensive explorations on the tributaries of the Upper Amazon by a Peruvian, Sr. M. Albornoz, and observations by M. Raeckelboom on the country, \&c., between Susa and Kairwan.

\section{DR. LENZ ON THE SAHARA}

TN a paper which Dr. Oscar Lenz contributes to the Zeitschrift of the Berlin Geographical Society, he gives an authentic account of the results of his journey across the Sahara, from Tanger to Timbuktu, and thence to Senegambia. The real jour- ney was begun at Marrakesh, at the northern foot of the Atlas Mountains, where Dr. Lenz laid in his stores of provisions and changed his name and dress, travelling further under the disguise of a Turkish military surgeon. He crossed the Atlas and the Anti-Atlas in a south-western direction. The Atlas consists, first, of a series of low hills belonging to the Tertiary and Cretaceous formations, then of a wide plateau of red sandstone, probably Triassic, and of the chief range which consists of clay-slates with extensive iron ores. The pass of Bibanan is $125^{\circ}$ metres above the sea-level, and it is surrounded with peaks about 4000 metres high, whilst the Wad Sus Valley at its foot is but 150 metres above the sea. The Anti-Atlas consists of Palæozoic strata. On May 5, 1880, Dr. Lenz reached Tenduf, a small town founded some thirty years ago, and promising to acquire great importance as a station for caravans. The northern part of the Sahara is a plateau 400 metres high, consisting of horizontal Devonian strata which contain numerous fossils. On May 15 Dr. Lenz crossed the moving sand-dunes of Igidi, a wide tract where he observed the interesting phenomenon of musical sand, a sound like that of a trumpet being produced by the friction of the small grains of quartz. But amidst these moving dunes it is not uncommon to find some grazing-places for camels, as well as flocks of gazelles and antelopes. At El Eglab Dr. Lenz found granite and porphyry, and was fortunate enough to have rain. Thence the character of the desert becotnes more varied, the route crossing sometimes sandy and sometimes stony tracts or sand-dunes, with several dry river-beds running east and west between them. On May 29 he reached the salt works of Taudeni, and visited the ruins of a very ancient town, where numerous stone implements have been found. Here he crossed a depression of the desert only 145 to 170 metres high, while the remainder of the desert usually reaches as much as 250 to 300 metres above the sea-level; and he remarks that throughout his journey he did not meet with depressions below the sea-level. The schemes for flooding the Sahara are therefore hopeless and misleading. The landscape remained the same until the wide Alfa fields, which extend north of Arauan. This little town is situated amidst sand-dunes devoid of ve retation, owing to the hot southern winds. Four days later Dr. Lenz was in Timbuktu, whence he proceeded west to St. Louis. During his forty-three days' travel through the Sahara Dr. Lenz observed that the temperature was not excessive; it usually was from $34^{\circ}$ to $36^{\circ}$ Celsius, and only in the Igidi region it reached $45^{\circ}$. The wind blew mostly from north-west, and it was only south of Taudeni that the traveller experienced the hot south winds (edrash) of the desert. As to the theory of north-eastern tradewinds being the cause of the formation of the desert, Dr. Lenz remarks that he never observed such a wind, nor did his men; it must be stopped by the hilly tracts of the north. Another important remark of Dr. Lenz is what he makes with respect to the frequent description of the Sahara as a sea-bed. Of course it was under the sea, but during the Devonian, Cretaceous, and Tertiary periods; as to the sand which covers it now, it has nothing to do with the sea : it is the product of destruction of sandstones by atmospheric agencies. Northern Africa was not always a desert, and the causes of its being so now must be sought for, not in geological, but in meteorological inftuences.

\section{SCIENTIFIC SERIALS}

Fournal of Anatomy and Phy'siology, vol. xvi., part r, October, I881, contains-Dr. D. J. Cunningham, on the relation of nerve-supply to muscle-homology.-Dr. Gibson, the action of duboisia on the circulation.-J. F. Knott, the cerebral sinuses and their variations.-Dr. G. Barling, primary growth from bone, resembling in some of its features scirrhus carcinoma of the breast.-Doctors George and F. Elizabeth I Hoggan, the comparative anatomy of the uterine lymphatics (plates $\mathbf{I}$ and 2), -Dr. H. Ashby, transposition of the aorta and pulmonary artery in a child of seven months.-Dr. W. Stirling, some points in the histology of the newt, and on the nerves of the lungs of the newt (plates 3 and 4).-Dr. Garson, on pelvimetry (plate 5).Prof. Turner, cranial characters of the Admiralty Islanders. Report on physiology, and anatomical notes.

The American Naturalist for November, $188 \mathrm{r}$, contains : W. $\mathrm{K}$. Higley, on the general and microscopical characters of the peach tree affected with the "yellows."-W. H. Dall, on the so-called Chukchi and Namolló people of Eastern Siberia.-W. H. Edwards, the length of life in butterflies.-H. D. Minot notes on the migrations of birds.-V. Havard, on Sotol.-E, 
D. Cope and A. S. Packard, jun., on the fauna of Nickajack Cave. Many miles were explored, and no end reached. The invertebrate fauna of the caves proved very considerable, and several new species are described and figured; one of the most interesting is the blind crayfish (Orconectes hamulatus, Cope).Recent Literature, Scientific News, \&c.

Rivista Scientifico-Industriale, No 18, October 15.-Malfatti's fossil Italian insects.-On the rectification of the cycloid, by Prof. Dainelli,

Verhandlungen der k.k. geologischen Reichsanstalt, No. I4, September 30.- Inclosures of foreign stones in crystalline limestone, by T. Fuchs. - Picrite-porphyry of Steierdorf, by E. Hussak,-On tentaculites, by O. Novak.-A note on the diluvium of Masenderan in Persia, by E. Tietze,-Travellers' reports.

Fournal of the Astatic Society of Bengal, vol. 1. part 2, No. 3, 1881 (October 22). - Geoffrey Nevill, on new or little-known mollusea of the Indo-Malayan fauna (plates 5 to 7). - Dr. O. Feistmantel, a sketch of the history of the fossils of the Indian Gondwána system.--Prof. V. Ball, additional note on the iden. tification of the ancient diamond mines visited by Tavernier.- J. Wood-Mason and Lionel de Nicéville, list of diurnal Lepidopiera inhabiting the Nicobar Islands.

Reoue des Sciences Naturelles, tome I, série $3^{\mathrm{e}}$, No. I, September, I88r, contains:-P. Gazalis de Fondouce, on Tertiary man in Portugal.-Prof. S. Berggren, on the prothallus and on the embryo of Azolla (plate I).-G. M. Viguier, studies on the formation of tufas of the present epoch.-Dr. P. Amans, anatomical and physiological researches on the larva of Aischno grandis (plate 2). - Account of the Zoological Station at Cette.

Revue internationale des Sciences biologiques, October, I88r, contains :-M. Bochefontaine, on the effects of the obstruction of the coronary arteries on the heart's action.-Jules Soury, on the modern doctrine of hylozoism (the doctrine which considers matter as living).-. Prof. Hanstein, protor lasm considered as the basis of animal and vegetable life.-Dr. W. Roberts, on the digestive ferments.

THE last number of the Fournal of the Russian Chemical and Physical Society contains, besides the minutes of proceedings, papers by Prof. Menshutkin, on the etherification of polybasic acids ; on the bromides of vinyle, and on cholic acid, by $M$. Kutcheroff; on the affinities of sulphur with metals, and on the means of discovering cadmium in presence of copper, by $M$. Orlovsky; and on the potential of hydrostatic pressures, by M. Latchinoff.

\section{SOCIETIES AND ACADEMIES \\ LONDON}

Royal Society, December 8.--"On the Coefficients of Contraction and Expansion by Heat of the Iodide of Silver AgI ; the Iodide of Copper $\mathrm{Cu}_{2} \mathrm{I}_{2}$; and of five Alloys of these Iodides," by G. F. Roclwell, F.R.A.S., F.C.S., Science Master in Marlborough College.

The experiments herein described are a continuation of those relating to the anomalous expansion by heat of certain iodides, published at intervals during the last five years in the Proceeding of the Royal Society. New determinations of the coefficients of iodide of silver are given. Certain physical and chemical properties of cuprous iodide are detailed, and its coefficient of expansion is determined. Five compounds or alloys were prepared, and their physical characteristics examined. They pos sessed the following composition, and percentage of iodide of silver :-

$\begin{array}{lc}\text { Composition. } & \text { Percentage of Iodide of Silver. } \\ \mathrm{Cu}_{2} \mathrm{I}_{2} \cdot \mathrm{AgI} & 38^{\circ} \cdot 2233 \\ \mathrm{Cu}_{2} \mathrm{I}_{2} \cdot 2 \mathrm{AgI} & 55^{\circ} 3066 \\ \mathrm{Cu}_{3} \mathrm{I}_{2} \cdot 3 \mathrm{AgI} & 64^{\circ} 9884 \\ \mathrm{Cu}_{2} \mathrm{I}_{2} \cdot 4 \mathrm{AgI} & 7 \mathrm{I}^{\prime} \cdot 2225 \\ \mathrm{Cu}_{2} \mathrm{I}_{2} \cdot 12 \mathrm{AgI} & 88 \cdot 1304\end{array}$

They are compared with the five chlorobromiodides of silver previously examined by the author (Proc. Roy. Soc. vol, xxy. p. 303), and with the lead-silver iodide alloy last described (Proc. Roy. Soc. vol. xxxii. p. 540).

The following are some of the results observed in connection with the new copper-silver iodide alloys :-

"I. The specific gravity varies but slightly, viz, from 5 "7302 to $5.695^{\circ}$, and is a little above the mean specific gravity of the constituents."

" 2 . The melting points are in all cases much lower than that of either iodide of silver or iodide of copper, for while the former is $527^{\circ} \mathrm{C}$., and the latter $60 \mathrm{x}^{\circ} \mathrm{C}$., the highest melting-point of any one of the alloys is $514^{\circ} \mathrm{C}$., and the lowest $493^{\circ} \mathrm{C}$.

' 3 . Some of the alloys possess three points of similar density, and some two, at different temperatures. They are resinous in fracture, and transparent in thin layers. When pulverised they furnish brilliantly yellow powders, unaffected by light.

" 4 . When heated in a current of carbonic anbydride they volatilise very slowly. Heated in dry oxygen iodine is freely evolved, and oxide of copper appears on the surface of the mass. When heated in dry hydrogen hydriodic acid is produced, and the metal is reduced.

" 5. The coefficients of expansion of the alloys below the point at which contraction on heating commences, was found to decrease as the percentage of iodide of silver was augmented.

" 6 . While the iodide of silver commences its considerable contraction at $142^{\circ} \mathrm{C}$., the five chlorobromiodides of silver, the percentage of iodide of silver in which varies from $26 \cdot 1692$ to $73^{\circ} 9285$, and the lead-silver iodide alloy, the percentage of iodide of silver in which amounts to $33^{\circ} 794$, all commenced their contraction at $124^{\circ} \mathrm{C}$., that is $18^{\circ} \mathrm{C}$. lower, although the coefficients of expansion of the associated bodies necessarily differ. Thus it would appear that $124^{\circ} \mathrm{C}$. is the temperature at which iodide of silver commences its passage from the crystalline into the amorphous condition when freed from the attraction of its "own molecules, provided no other attraction or influence supervenes; while the attraction exerted when it exists unalloyed with any other substance, and when its molecules are hence much nearer to each other, raises the point at which the change commences to $142^{\circ} \mathrm{C}$.

" 7 . When the same result was looked for in the case of the copper-silver iodide alloys, it was not found. In fact the presence of the iodide of copper, instead of promoting the assimilation of molecular motion and lowering the point at which the change from the crystalline into the plastic condition commences was found to considerably raise it; although the coefficient of expansion of the iodide of copper is lower than that of either chloride or bromide of silver or of the icdide of lead which enter into the compozition of the other alloys. Thus :

Percentage of iodide of silver in the Temperature at which contraction copper-silver iodide alloys.

$\begin{array}{ll}38.2232 & 284^{\circ} \mathrm{C} . \\ 55^{\circ} .3066 & 233^{\circ} \\ 64^{\circ} .9886 & 214^{\circ} \\ 71.2225 & 199^{\circ} \\ 88.1304 & 153^{\circ}\end{array}$

Hence while $66 \cdot 206$ per cent. of iodide of lead lowered the point of change $18^{\circ} \mathrm{C}$., the presence of $61^{\circ} 7767$ per cent. of iodide of copper raised it $\mathrm{r}_{42} 2^{\circ} \mathrm{C} . "$

A general discuscion of the results is given and the special properties of the alloys described.

Linnean Society, December 15.-G. Busk, F.R.S., in the chair.-Prof. T. S. Cobbold exhibited a large guinea-worm (Dracunculus) taken from a pony, and forw arded by Vet. Surg. Frederick Smith from Madras. Only one previous instance of the occurrence of this parasite in the hor:e has been mentioned, and its authenticity was doubted by Fedschenko and other helmintbologists. - Mr. G. S. Boulger brought before the meeting a set of large papier-maché models of insectivorous plants made at Breslau by Herr Brendel under the superintendence of Prof. Cohn. Mr. Boulger explained their adaptation for teachin: purposes, and made special referenre by a diagram to the varic us stages and physiotogical distinctions of these plants, viz. frcm simple viscidity of surface to the more complex apparatus in Dionæa and Aldrovanda.-Mr. T. Christy called attention to a volume of the Annual Report of the Commissioner of Agriculture, Washington, U.S. (I879), wherein was embodied much valuable information on the insects and parasites destructive to crops, \&c.-Prof. Duncan thereafter gave the gist of a paper on the morphology of the test of the Temnopleuraidæ. -A paper by Dr. Maxwell Masters followed, dealing with a new species of cotton (Gossypium Kirkii) from East Tropical Africa. It has an interest historically from being probably the origin of very numerons cultivated varieties. It was obtained by Sir John Kirk growing wild at Dar Salam, Dr. Masters regards it as most nearly allied to $G$. bartadense, which is most 